\title{
The Entire Body Quiver Effect on Lower Extremity Flexibility in Healthy Young Female
}

\author{
Xiaohui Lin1, Karim Dad Sharifi², Hizbullah Bahir ${ }^{2}$ \\ ${ }^{1}$ Sport Coaching Department Beijing Sport University, Beijing, China \\ ${ }^{2}$ Physical Education Department, Education Faculty, Kandahar University, Kandahar, Afghanistan \\ Email: 1442529482@qq.com, karim.hotak786@gmail.com, bahir.hizbullah@hotmail.com
}

How to cite this paper: Lin, X.H., Sharifi, K.D. and Bahir, H. (2021) The Entire Body Quiver Effect on Lower Extremity Flexibility in Healthy Young Female. Open Access Library Journal, 8: e7953.

https://doi.org/10.4236/oalib.1107953

Received: September 12, 2021

Accepted: October 9, 2021

Published: October 12, 2021

Copyright () 2021 by author(s) and Open Access Library Inc.

This work is licensed under the Creative Commons Attribution International License (CC BY 4.0).

http://creativecommons.org/licenses/by/4.0/

(c) (i) Open Access

\begin{abstract}
Flexibility is one of the most important parts of the normal muscular system. Thus, before this when athletes start the competitions and exercises they should warm up their body muscles in regular and systematic ways. In the studies that were carried out in this field, the effects of flexibility difference which has an alike impact on the right and left feet as well difference were not declared. In this research, the variation of flexibility also cleared which do not have a similar impact on feet; as a result, there is only the existence of difference. The objective of the study is the effects of WBV on lower extremity organs of Healthy young females. About materials and methods, a total of 30 healthy young women with an average age of $22 \pm 4$ years participated in the present study. Their resilience was measured using passive knee extension tests, hip flexibility, testing and modified sessions and interventions before and after reaching the test. Participants stand on WBV equipment $(\mathrm{f}=25 \mathrm{~Hz}$, Amp $=2 \mathrm{~mm} 5 \times 1$ minute hold +60 seconds rest) in semi-squat position. The items of the participant case were analyzed by using IBM 26 version of Statistical Package for Social Science (SPSS). After WBV, hamstrings and hip flexors, as well as general flexibility, increased significantly $(\mathrm{P}=0 / 001)$. The results showed that before $\mathrm{WBV}$, there was a significant difference in hamstring and hip flexion between both legs $(\mathrm{P} \leq 005)$, but after WBV, there was no significant difference in hip flexion flexibility. The findings of the study indicate that WBV appears to be appropriate training for lower extremity muscle flexibility. The results of this study showed that WBV can be an effective training method to increase flexibility and due to the contradictory results in the benefits of using stretching in training programs may be used as a complementary method to improve flexibility.
\end{abstract}

\section{Subject Areas}

Sports Science 


\section{Keywords}

Flexibility, Muscles, Whole Body Vibration

\section{Introduction}

\subsection{Research Background}

Flexibility is considered an important and effective factor in physical health. Range of motion is one of the main components of the normal functioning of the musculoskeletal system. The maximum muscle length is necessary to obtain the most detailed range of motion, and these two factors affect the functional activities of individuals and the performance of the athlete, so that increasing flexibility is an essential component in physiotherapy and exercise [1]. Goals that can be expected from increasing flexibility before sporting events are: adequate range of motion in order to perform optimal sports activity as well as reduce muscle stiffness or increase compliance, which from a theoretical point of view reduces the risk of injury [2].

\subsection{Objective of the Study}

The objective is to determine the effect of WBV on flexibility in Young females.

\subsection{Research Questions}

What effect does Whole body vibration have on lower limb flexibility in a healthy young female?

\section{Literature Review}

The flexibility of the motion range in one or group of joints is the ability to move the joints in a useful way. Flexibility training includes tensile training to increase muscle length and may include activities such as yoga or Tai. For this reason, stretching exercises, especially static stretching to increase flexibility, are a constant part of athletes' training programs and are generally recommended before training or participating in sports competitions. According to the International Association of Strength and Fitness before or during sports competitions, a period of introductory activities increases blood flow and metabolic activity, increases flexibility and improves joint range of motion, improves performance and transfer. From rest to exercise, it is essential that this introductory program includes $5-10$ minutes of low-intensity aerobic exercise followed by $8-12 \mathrm{mi}-$ nutes of stretching [3]. Several studies have reported the benefits of using leggings and increasing flexibility in groups was significantly reduced. Gremion (2005) is in a review of athletes [4]. In a retrospective study in 1999, Cross et al. reported that the incidence of muscle-tendon strains in stretched muscle the effect of stretching on the risk of sports injury and athletic performance concluded that stretching plays an important role in increasing athletic performance by in- 
creasing muscle-joint mobility and lack of mobility increases the risk of injury [5]. Recently, however, some studies have reported conflicting results from the use of stretching in the preparation program, and some have even had negative effects on it. In two studies, Pope et al. questioned the effect of stretching on muscle risk [6]. In 2002, Herbert also concluded in a systematic study that stretch has no effect on the risk of muscle injury [7]. A number of studies have shown that stretching, especially static stretching, can significantly reduce the most muscle function such as power generation, vertical jump performance, running time [8] [9]. WBV, on the other hand, is a relatively new approach to exercise that is used in exercise and rehabilitation to improve neuromuscular function and is recognized as an effective and interesting complement to traditional forms of exercise for athletes, the elderly, and the healthy [10]. This method of physical fitness stimulates sensory receptors, especially the muscle spindle, by creating oscillating movements that are transmitted to the whole body, and by activating the alpha motor response of neurons, it causes muscle contractions [11]. Studies have shown that WBV, in the long run, can increase muscle strength, improve postural stability and increase bone density [12]. Given the positive effects mentioned, this emerging exercise intervention has become very popular for rehabilitation, fitness and general health. Few studies have tested the effect of WBV on flexibility [13] [14]. Therefore, it seems that the use of WBV, which can simultaneously increase flexibility and increase muscle function, as a preliminary activity before participating in other exercises can be interesting and effective, and due to some negative effects of stretching in ready exercises. Instrumentation may be an alternative to this method. Therefore, our aim in this study was to investigate the immediate effects of WBV on lower limb flexibility [15] [16].

\section{Materials and Methods}

\subsection{Methods}

Clinical studies using routine laboratory tests can provide important opportunities to investigators, especially to those with limited resources such as provide interesting information for sports coaches. Participants in this study were 30 healthy young women $(18$ - 26) years, $(45-65) \mathrm{kg}$, tall height $(1.40-1.80) \mathrm{m}$, who were selected from China (Beijing Spot University) girls based on improbable sampling of easy type. Participants completed and signed the informed consent form before participating in the study. Inclusion criteria were: 18 - 26 years old women, no vision problems, no epilepsy and seizures, no bone fractures and tendon strain in the last six weeks, no migraine, no kidney and bladder stones, no participation in exercise programs and strength to Continuous, no history of lower extremity lesions such as hip, knee and ankle. Exclusion criteria included: inability to perform the test and unwillingness to continue cooperation. The items of the participant case were analyzed by using IBM 24 version of Statistical Package for Social Science (SPSS). During the introductory session, participants were thoroughly introduced to the intervention process and how to perform the 
tests. At the beginning of the intervention session, participants had a general preparation method including 5 minutes of walking on a treadmill at a speed of $4 \mathrm{~km} / \mathrm{h}$. immediately afterwards, an initial assessment of flexibility was made. Then the intervention was performed and after the intervention, the final evaluation of flexibility was performed.

\subsection{Flexibility Assessment}

In this study, flexibility was assessed in three tests.

\subsubsection{Modified Sit and Reach Test}

This test is a common criterion for evaluating hip and lower back flexibility [17] [18]. To perform this test, the person sits on the floor with their head and back completely against the wall. The knees were fully extended and the ankles were in the dorsiflexion position of neutral. First, the soles of the feet (barefoot) were placed in contact with the sit and reach box [19] [20]. In this case, the person first placed his hands on top of each other and straightened his elbows without separating his head and back from the wall. The distance from the fingertips to the edge of the box was measured with a ruler and considered as a zero or starting point, then the person slowly leaned forward and held the hand as parallel as possible [19] [21]. The box and the ruler move forward. The final position is maintained and in this case, the distance obtained is recorded. This test is repeated 3 times and the best size was used for statistical calculations.

\subsubsection{Passive Knee Extension Test}

This test is a valid test to evaluate hamstring flexibility. To perform this test, the person lies in an open arch, with the opposite limb hanging from the knee from the bed to fix the pelvis. Then, in the test limb, the protrusions of the great femoral trochanter, the external epicondyle of the thigh, and the location of the external ankle were marked by a marker [22] [23]. The test limb was placed at a 90-degree flexion angle from the hip area using a Lafayette instrument company the USA and was fixed with a strap. The examiner placed the axis of the goniometer on the lateral surface of the external epicondyle of the femur, and the fixed, telescopic arm of the goniometer was positioned along the lateral surface of the thigh so that its end was along the large trochanter, and the moving telescopic arm goniometer along the lateral surface of the tibia. It was placed with the end along the outer ankle. In this case, the knee joint angle was set at 90 degrees [24] [25]. The tester then inactively raises the person's leg until it feels stiff. In this case, the numerical value of the goniometer was read. This operation was repeated three times and the best result was recorded [26] [27].

\subsubsection{Hip Flexion Test}

This test is a criterion for evaluating the flexibility of hip flexors [28] [29]. At first, the person with the arch was lying down and both feet were in a completely straight position. Landmarks marked with a marker included: the large femoral trochanter, the external femoral epicondyle, and the external molto. The large 
trochanter and movable arm were placed along the outer ankle [30]. The person was then asked to bend the other leg and bring the knee closer to the chest with the help of the hands [30]. In this case, the flexion angle of the knee in the test leg was read from the goniometer. This test was repeated three times and the best result was used statistically. Each of these assessments was performed for both right and left feet of the specimens.

\section{Finding}

\section{How to Perform the Treatment Plan}

The vibration was performed by a WBV device made by the American company Power Plate Next Generation. Each person experienced vibration in five sets of 60 seconds and 60 seconds of rest between sets, the frequency of which was 30 $\mathrm{Hz}$ and the amplitude was set to $2 \mathrm{~mm}$. The person stood on the platform of the machine without shoes and with socks in a semi-squat position. The reason for choosing this standing position is that according to the research, this position prevents the transmission of vibration to the head and the vibration waves in the hip area are completely damped. He stepped on both feet and kept his hands stretched, but if the balance was disturbed, he could grab the handrail of the device. Finally, all flexibility assessment tests were performed again for the samples SPSS 24 software was used T-independent test for statistical analysis. First, Kolmogorov-Smirnov test was used to determine the normal distribution of data. The results of this test showed that the distribution of demographic variables has a normal distribution $(\mathrm{P}<0.05)$. Then the mean and standard deviation of all variables were calculated before and after vibration. Comparison of flexibility mean and possible changes before and after vibration, in right and left legs, as well as flexibility comparison between two legs before and after vibration, was performed using paired $t$-test with a significance level of $P \geq 0.05$.

Table 1 the characteristics of the respondents in this study is as follow: 30 (100\%) Female; the categories of their Height are between $(1.40-1.50) \mathrm{h}, 8$ (26.7\%); between (1.51 - 1.60) h, 10 (33.3\%); between (1.61 - 1.70) h, 9 (30\%); between $(1.71-1.80)$ h, $3(10 \%)$. Their Height are between weight $(45-49) \mathrm{kg}, 2$ (6.7\%); (50 - 54) kg, 2 (6.7\%); (55 - 59) kg, 7 (23.3\%); (60 - 64) kg, 11 (36.7\%); 65 $\mathrm{kg}$, Upper $8(26.7 \%)$. In the study, the ages of the respondents are as follow: 9 (30\%) between $18 \& 20$ years; 13 (43.3\%) between $21 \& 23$ years; 8 (26.7\%) between $24 \& 26$. The age categories show that most of the respondents were ove between $21 \& 23$ years old. Paired t-test results showed that after WBV, hamstring flexibility and hip flexors in both legs (right and left (significantly increased) $(\mathrm{P}=0.001)$ (Table 2).

Table 2 Turned out the results of paired t-test showed that the general flexibility of the body before vibration was 3.839 degrees and after vibration was 3.644 degrees, which increased significantly compared to before $(\mathrm{P}=0.001)$.

The results of paired $\mathrm{t}$-test showed that the hamstring flexibility before the intervention was significantly different between the right and left legs $(\mathrm{P}=$ 
Table 1. Shows the demographic data of the participants.

\begin{tabular}{cccc}
\hline & \multicolumn{2}{c}{ Demographic Data of the participant } \\
\cline { 2 - 4 } & Characteristics & Frequency & Percentage \\
\hline \multirow{2}{*}{ Gender } & Female & 30 & $100 \%$ \\
\hline \multirow{3}{*}{ Height } & Between $1.40-1.50 \mathrm{~cm}$ & 8 & $26.7 \%$ \\
& Between $1.51-1.60 \mathrm{~cm}$ & 10 & $33.3 \%$ \\
& Between $1.61-1.70 \mathrm{~cm}$ & 9 & $30 \%$ \\
& Between $1.71-1.80 \mathrm{~cm}$ & 3 & $10 \%$ \\
\hline \multirow{3}{*}{ Weight } & Between $45-49 \mathrm{~kg}$ & 2 & $6.7 \%$ \\
& Between $50-54 \mathrm{~kg}$ & 2 & $6.7 \%$ \\
& Between $55-59 \mathrm{~kg}$ & 7 & $23.3 \%$ \\
& Between $60-64 \mathrm{~kg}$ & 11 & $26.7 \%$ \\
\hline \multirow{2}{*}{ Age } & 65 Upper & 8 & $30 \%$ \\
& Between $18-20$ years old & 9 & $43.3 \%$ \\
& Between $21-23$ years old & 13 & $26.7 \%$ \\
\hline
\end{tabular}

Table 2. Comparison of hamstring flexibility and hip flexibility in right and left legs in terms of before and after WBV $(\mathrm{n}=30)$.

\begin{tabular}{|c|c|c|c|c|c|c|c|c|}
\hline & \multicolumn{8}{|c|}{ Paired Differences } \\
\hline & \multirow[t]{2}{*}{ Mean } & \multirow[t]{2}{*}{$\begin{array}{c}\text { Std. } \\
\text { Deviation }\end{array}$} & \multirow[t]{2}{*}{$\begin{array}{l}\text { Std. } \\
\text { Error } \\
\text { Mean }\end{array}$} & \multicolumn{2}{|c|}{$\begin{array}{l}\text { 95\% Confidence } \\
\text { Interval of the } \\
\text { Difference }\end{array}$} & \multirow[t]{2}{*}{$t$} & \multirow[t]{2}{*}{$\mathrm{df}$} & \multirow[t]{2}{*}{$\begin{array}{c}\text { Sig. } \\
\text { (2-tailed) }\end{array}$} \\
\hline & & & & Lower & Upper & & & \\
\hline $\begin{array}{l}\text { Hamstring } \\
\text { flexibility } \\
\text { (degree) } \\
\text { Right foot }\end{array}$ & 4.000 & 6.080 & 1.110 & 1.730 & 6.270 & 3.603 & 29 & 0.001 \\
\hline $\begin{array}{l}\text { Flexibility of hip } \\
\text { flexors (degree) } \\
\text { Right foot } \\
\text { (Antes) }\end{array}$ & 4.800 & 8.277 & 1.511 & 1.709 & 7.891 & 3.176 & 29 & 0.004 \\
\hline $\begin{array}{l}\text { Hamstring } \\
\text { flexibility } \\
\text { (degree) Left foot }\end{array}$ & 2.767 & 6.745 & 1.231 & 0.248 & 5.285 & 2.247 & 29 & 0.032 \\
\hline $\begin{array}{l}\text { Flexibility of hip } \\
\text { flexors (degree) } \\
\text { Left foot (Next) }\end{array}$ & 5.333 & 8.884 & 1.622 & 2.016 & 8.651 & 3.288 & 29 & 0.003 \\
\hline
\end{tabular}

0.0001). Also after the WBV, the hamstring flexibility between the right and left legs were significantly different. $\mathrm{P}=0.001$. The changes in hamstring flexibility in the right leg increased by 3.176 degrees after WBV and in the left leg by 3.288 degrees. The comparison of the changes between the two legs showed that the hamstring flexibility in the left foot after WBV there was a significant increase $(\mathrm{P}=0.04)$ Table 3 . The results of paired $\mathrm{t}$-test also showed that the flexibility of hip flexors before the intervention was significantly different between the right and left legs $(\mathrm{P}=0.04)$. But after WBV, the flexibility of hip flexors between the 
Table 3. Comparison of hamstring flexibility and flexibility between right and left foot in terms of before and after WBV $(\mathrm{n}=30)$.

\begin{tabular}{|c|c|c|c|c|c|c|c|c|}
\hline & \multicolumn{8}{|c|}{ Paired Samples Test } \\
\hline & \multirow[t]{2}{*}{ Mean } & \multirow[t]{2}{*}{$\begin{array}{c}\text { Std. } \\
\text { Deviation }\end{array}$} & \multirow[t]{2}{*}{$\begin{array}{c}\text { Std. Error } \\
\text { Mean }\end{array}$} & \multicolumn{2}{|c|}{$\begin{array}{l}95 \% \text { Confidence } \\
\text { Interval of } \\
\text { the Difference }\end{array}$} & \multirow[t]{2}{*}{$\mathbf{t}$} & \multirow[t]{2}{*}{$\mathrm{df}$} & \multirow[t]{2}{*}{$\begin{array}{c}\text { Sig. } \\
\text { (2-tailed) }\end{array}$} \\
\hline & & & & Lower & Upper & & & \\
\hline $\begin{array}{l}\text { Hamstring } \\
\text { flexibility } \\
\text { (degree) } \\
\text { Right foot }\end{array}$ & 3.600 & 5.137 & 0.938 & 1.682 & 5.518 & 3.839 & 29 & 0.001 \\
\hline $\begin{array}{l}\text { Flexibility of hip } \\
\text { flexors (degree) } \\
\text { Right foot }\end{array}$ & 1.900 & 3.111 & 0.568 & 0.738 & 3.062 & 3.345 & 29 & 0.002 \\
\hline $\begin{array}{l}\text { Hamstring } \\
\text { flexibility } \\
\text { (degree) } \\
\text { Left foot }\end{array}$ & 3.600 & 5.411 & 0.988 & 1.579 & 5.621 & 3.644 & 29 & 0.001 \\
\hline $\begin{array}{l}\text { Flexibility of hip } \\
\text { flexors (degree) } \\
\text { Left foot }\end{array}$ & 1.100 & 7.508 & 1.371 & -1.704 & 3.904 & 0.802 & 29 & 0.429 \\
\hline
\end{tabular}

right and left legs were not significantly different. $03 p=0.03$ Changes in the flexibility of the hip flexors in the right and left legs, changes between the two legs showed that there was no improvement in flexibility after WBV. The data in the above tables have been analyzed by thy SPSS program using the t-independent Test.

\section{Discussion}

Flexibility is an important component of passive muscle function and is the ability of skeletal muscles to lengthen without arousal [1]. In other words, when a muscle is stretched passively, flexibility describes a physiological relationship between passive muscle lengths and its resistance to stretch [4]. In this study, the immediate effects of WBV on lower limb flexibility in 30 healthy young women were investigated. For this purpose, the flexibility of the hamstring muscles, hip flexors and general flexibility of the body were evaluated before and after vibration. The results showed that vibration significantly increased the flexibility of hamstring muscles, hip flexors in the left and right legs and general flexibility of the body. Our findings on the effect of vibration on flexibility in this study are in line with the results of studies by other researchers who examined the immediate effect of vibration on flexibility [3] [20] [21] [23]. In 2009, Jacobs et al. investigated the immediate effect of vibration at $26 \mathrm{~Hz}$ and stationary cycling at 50 woman muscle strength, general body flexibility, and heart rate. The results related to flexibility showed that flexibility after vibration intervention was significantly increased compared to stationary bicycle [4]. In 2005, Cochrane et al. 
examined the immediate effect of $26 \mathrm{~Hz}$ vibration, $6 \mathrm{~mm}$ amplitude, and vertical displacement in six different positions on jump height, grip strength, and flexibility. Participants in this study were female athletes. The results showed a significant increase in flexibility following vibration. Studies such as ours have evaluated the immediate effects of WBV on flexibility, although the method used is different from ours and participants in some studies are athletes. In some studies, the effect of WBV on flexibility has been studied for a longer period of time. However, the results obtained are consistent with our study, which evaluated the immediate effect of WBV. For example, in 2013, Karatrantou et al. examined the effect of the WBV treatment program on flexibility for 16 sessions and reported a 13\% improvement (Rittweger, 2010). A number of studies have examined the combined effect of vibration and stretch, with results showing greater effects on improved flexibility than stretch alone [29]. In 2006, Tiller examined the effect of WBV with a vibration frequency of $28 \mathrm{~Hz}$ and $10 \mathrm{~mm}$ amplitude on the motor range of motion of the hamstring muscle. In this study, contrary to our study, which examined the effect of WBV on flexibility alone, they examined the effect of WBV by adding WBV to the first intervention, the static stretch, by actually combining these two interventions. Both groups had significantly increased hamstring flexibility, although the WBV group had a greater increase in range of motion (30\%) than the control group [4]. These results, similar to our findings, confirm the effectiveness of the WBV. The result of the present study differs from the results of some studies. For example, a study conducted by Coin and Nash in 2008 examined the effect of vibration alone, stretching and stretching alone on the range of motion of the knee, and showed that vibration alone, along with stretching, has no effect on increasing the amplitude of hamstring flexibility [6]. In this study, several factors can be mentioned as the reason for this difference with the findings of our study, including the difference in the method used to assess the range of motion of the knee joint in the study dynamically with the help of video and facial software. Another difference was the use of a vibrating platform that was used topically on the hamstring muscle in this study. In addition, the participants in this study, unlike our study, were healthy men, and since gender is a factor affecting flexibility, it can also affect the results obtained. In general, due to the emergence of this intervention, since a single protocol has not yet been proposed to use vibration to increase flexibility, researchers use different methods in different studies [11]. Therefore, various factors such as therapeutic parameters (frequency, amplitude, time of use), body condition, gender and athlete can be effective in achieving contradictory results [11]. We will increase traction tolerance and increase range of motion [15]. Vibration can stimulate the GTO, followed by inhibition of contraction and relaxation [14]. In addition to the above, vibration can increase the sensitivity of the stretch reflex and the activity of antagonist's muscles is inhibited by inhibitory neurons, which leads to changes in intramuscular coordination patterns. Vibration affects the firing of $\alpha$ and $\delta$ neurons with rapid changes 
in muscle length, which in turn can cause changes in muscle flexibility [13]. Vibration also causes vasodilation and increased blood flow to the skin, deep vessels, and muscles under vibration, which in turn increases muscle temperature, which may lead to decreased tissue viscosity and increased muscle elasticity [7].

\section{Conclusion}

The results of this study showed that WBV can be an effective training method to increase flexibility and due to the contradictory results in the benefits of using stretching in training programs may be used as a complementary method to improve flexibility.

\section{Conflicts of Interest}

The authors declare no conflicts of interest.

\section{References}

[1] Pope, R., Herbert, R. and Kirwan, J. (1998) Effects of Ankle Dorsiflexion Range and Pre-Exercise Calf Muscle Stretching on Injury Risk in Army Recruits. Australian Journal of Physiotherapy, 44, 165-172. https://doi.org/10.1016/S0004-9514(14)60376-7

[2] Morrin, N. and Redding, E. (2013) Acute Effects of Warm-Up Stretch Protocols on Balance, Vertical Jump Height, and Range of Motion in Dancers. Journal of Dance Medicine \& Science: Official Publication of the International Association for Dance Medicine \& Science, 17, 34-40. https://doi.org/10.12678/1089-313X.17.1.34

[3] Alabi, A. (2018) Effective Planning as a Factor of Educational Reform and Innovation in Nigeria Effective Planning as a Factor of Educational Reform and Innovation in Nigeria.

[4] Artero, E.G., Espada-Fuentes, J.C., Argüelles-Cienfuegos, J., Román, A., Gómez-López, P.J. and Gutiérrez, A. (2012) Effects of Whole-Body Vibration and Resistance Training on Knee Extensors Muscular Performance. European Journal of Applied Physiology, 112, 1371-1378. https://doi.org/10.1007/s00421-011-2091-0

[5] Bautmans, I., Van Hees, E., Lemper, J.C. and Mets, T. (2005) The Feasibility of Whole Body Vibration in Institutionalised Elderly Persons and Its Influence on Muscle Performance Balance and Mobility: A Randomised Controlled Trial. BMC Geriatrics, 5, Article No. 17. https://doi.org/10.1186/1471-2318-5-17

[6] Behm, D.G. (2018) The Science and Physiology of Flexibility and Stretching. https://doi.org/10.4324/9781315110745

[7] Chan, P.P. and Lowe, T.M. (2016) GtRNAdb 2.0: An Expanded Database of Transfer RNA Genes Identified in Complete and Draft Genomes. Nucleic Acids Research, 44, 184-189. https://doi.org/10.1093/nar/gkv1309

[8] Cochrane, D.J. and Stannard, S.R. (2005) Acute Whole Body Vibration Training Increases Vertical Jump and Flexibility Performance in Elite Female Field Hockey Players. British Journal of Sports Medicine, 39, 860-865. https://doi.org/10.1136/bjsm.2005.019950

[9] De Baranda, P.S. and Ayala, F. (2010) Chronic Flexibility Improvement after 12 Week of Stretching Program Utilizing the ACSM Recommendations: Hamstring Flexibility. International Journal of Sports Medicine, 31, 389-396. https://doi.org/10.1055/s-0030-1249082 
[10] Delecluse, C., Roelants, M. and Verschueren, S. (2003) Strength Increase after Whole-Body Vibration Compared with Resistance Training. Medicine and Science in Sports and Exercise, 35, 1033-1041. https://doi.org/10.1249/01.MSS.0000069752.96438.B0

[11] Sands, W.A., McNeal, J.R., Stone, M.H., Russell, E.M. and Jemni, M. (2006) Flexibility Enhancement with Vibration: Acute and Long-Term. Medicine and Science in Sports and Exercise, 38, 720-725. https://doi.org/10.1249/01.mss.0000210204.10200.dc

[12] Torvinen, S., Kannus, P., Sievänen, H., Järvinen, T.A.H., Pasanen, M., Kontulainen, S., Järvinen, T.L.N., Järvinen, M., Oja, P. and Vuori, I. (2002) Effect of Four-Month Vertical Whole Body Vibration on Performance and Balance. Medicine and Science in Sports and Exercise, 34, 1523-1528. https://doi.org/10.1097/00005768-200209000-00020

[13] Gibbings, S.L., Thomas, S.M., Atif, S.M., McCubbrey, A.L., Desch, A.N., Danhorn, T., Leach, S.M., Bratton, D.L., Henson, P.M., Janssen, W.J. and Jakubzick, C.V. (2017) Three Unique Interstitial Macrophages in the Murine Lung at Steady State. American Journal of Respiratory Cell and Molecular Biology, 57, 66-76. https://doi.org/10.1165/rcmb.2016-0361OC

[14] Harris, A. and Goodall, J. (2008) Do Parents Know They Matter? Engaging All Parents in Learning. Educational Research, 50, 277-289.

https://doi.org/10.1080/00131880802309424

[15] Hough, P.A., Ross, E.Z. and Howatson, G. (2009) Effects of Dynamic and Static Stretching on Vertical Jump Performance and Electromyographic Activity. Journal of Strength and Conditioning Research, 23, 507-512. https://doi.org/10.1519/JSC.0b013e31818cc65d

[16] Huberman, B. (2002) Raising Sexually Healthy Youth: Rights, Respect Responsibility \& Parent-Child Communication. Transition, 15, 1-14.

[17] Kinser, A.M., Ramsey, M.W., O’bryant, H.S., Ayres, C.A., Sands, W.A. and Stone, M.H. (2008) Vibration and Stretching Effects on Flexibility and Explosive Strength in Young Gymnasts. Medicine \& Science in Sports \& Exercise, 40, 133-140. https://doi.org/10.1249/mss.0b013e3181586b13

[18] Leu, E. and Price-Rom, A. (2006) Quality of Education and Teacher Learning: A Review of the Literature. USAID Educational Quality Improvement Project, Washington DC, 1, 28.

[19] Lundeberg, T., Nordemar, R. and Ottoson, D. (1984) Pain Alleviation by Vibratory Stimulation. Pain, 20, 25-44. https://doi.org/10.1016/0304-3959(84)90808-X

[20] Ghasemi, M., et al. (2013) Effects of Cyclic Static Stretch on Fatigue Recovery of Triceps Surae in Female Basketball Players. Biology of Sport, 30, 97-102. https://pubmed.ncbi.nlm.nih.gov/24744474

[21] Panchaud, C., Pii, J. and Poncet, M. (2000) Assessment of Curriculum Response in 35 Countries for the EFA Monitoring Report 2005: “The Quality Imperative”.

[22] Pantović, M., Madić, D., Popović, B., Batez, M. and Obradović, J. (2015) Efekti primene vibracionog treninga i treninga sa dodatnim spoljašnjim opterećenjem na razvoj snage kod 13-godišnjeg dečaka nakon lezije $\mathrm{m}$. biceps femoris i posttraumatske kalcifikacije. Vojnosanitetski Pregled, 72, 646-650. https://doi.org/10.2298/VSP140228040P

[23] Gajdosik, R.L. (2001) Passive Extensibility of Skeletal Muscle: Review of the Literature with Clinical Implications. Clinical Biomechanics, 16, 87-101. https://doi.org/10.1016/S0268-0033(00)00061-9

[24] Gerodimos, V., Zafeiridis, A., Karatrantou, K., Vasilopoulou, T., Chanou, K. and 
Pispirikou, E. (2010) The Acute Effects of Different Whole-Body Vibration Amplitudes and Frequencies on Flexibility and Vertical Jumping Performance. Journal of Science and Medicine in Sport, 13, 438-443.

https://doi.org/10.1016/j.jsams.2009.09.001

[25] Rittweger, J. (2010) Vibration as an Exercise Modality: How It May Work, and What Its Potential Might Be. European Journal of Applied Physiology, 108, 877-904. https://doi.org/10.1007/s00421-009-1303-3

[26] Santonja Medina, F.M., Sainz De Baranda Andújar, P., Rodríguez García, P.L., López Miñarro, P.A. and Canteras Jordana, M. (2007) Effects of Frequency of Static Stretching on Straight-Leg Raise in Elementary School Children. Journal of Sports Medicine and Physical Fitness, 47, 304-308.

[27] Shadmehr, A., Hadian, M.R., Naiemi, S.S. and Jalaie, S. (2009) Hamstring Flexibility in Young Women Following Passive Stretch and Muscle Energy Technique. Journal of Back and Musculoskeletal Rehabilitation, 22, 143-148.

https://doi.org/10.3233/BMR-2009-0227

[28] Watanabe, Y., Ohshima, H., Mizuno, K., Sekiguchi, C., Fukunaga, M., Kohri, K., Rittweger, J., Felsenberg, D., Matsumoto, T. and Nakamura, T. (2004) Intravenous Pamidronate Prevents Femoral Bone Loss and Renal Stone Formation during 90-Day Bed Rest. Journal of Bone and Mineral Research, 19, 1771-1778. https://doi.org/10.1359/JBMR.040811

[29] Weppler, C.H. and Magnusson, S.P. (2010) Increasing Muscle Extensibility: A Matter of Increasing Length or Modifying Sensation? Physical Therapy, 90, 438-449. https://doi.org/10.2522/ptj.20090012

[30] Zakas, A., Galazoulas, C., Doganis, G. and Zakas, N. (2006) Effect of Two Acute Static Stretching Durations of the Rectus Femoris Muscle on Quadriceps Isokinetic Peak Torque in Professional Soccer Players. Isokinetics and Exercise Science, 14, 357-362. https://doi.org/10.3233/IES-2006-0249 